\title{
Pengukuran usability pada learning management system perguruan tinggi menggunakan pedoman system usability scale
}

\section{Usability measurement in college learning management system using the guidance system usability scale}

\author{
Dimas Setiawan ${ }^{a}$, Naufal Rafianto ${ }^{b}$ \\ a,b Sistem Informasi, Universitas PGRI Madiun, Madiun, Indonesia \\ email:adimas.is.my.name@gmail.com, ${ }^{b}$ naufal.rafianto@gmail.com
}

\begin{tabular}{l}
\hline I N F O A R T I K E L \\
\hline Sejarah artikel: \\
Menerima 14 Juni 2020 \\
Revisi 9 Juli 2020 \\
Diterima 9 Juli 2020 \\
Online 17 Juli 2020 \\
\hline
\end{tabular}

Kata kunci:

kegunaan

LMS

Moodle

pengukuran

skala kegunaan sistem

Keywords:

LMS

measurement

Moodle

System Usability Scale usability

Style APA dalam menyitasi artikel ini:

Setiawan, D., \& Rafianto, N. (2020). Pengukuran usability pada learning management system perguruan tinggi menggunakan pedoman system usability scale. Teknologi: Jurnal Ilmiah Sistem Informasi, 10(1), 23-31.

\begin{abstract}
ABSTRAK
Kebijakan pemerintah di masa pandemi berdampak pada perubahan kegiatan pembelajaran di Universitas PGRI Madiun, di mana keseluruhan proses dilaksakan secara daring, salah satunya dengan memanfaatkan ELMA (e-learning Universitas PGRI Madiun). Dalam praktiknya, pengguna mengeluh ketika menggunakan platform tersebut, salah satunya terdapat beberapa tombol yang malfungsi, beberapa menu dashboard membuat bingung pengguna, dan masih banyak permasalahan lainnya. Namun, keluhan tersebut belum bisa terakomodasi dengan baik, sehingga membuat pengguna merasa kurang nyaman dalam menggunakan platform tersebut, sehingga diperlukan evaluasi untuk mengungkap kondisi usability ELMA. Hal ini perlu dilakukan mengingat salah satu misi dari ELMA adalah mendukung pembelajaran online melalui fitur yang sesuai dengan kebutuhan pengguna. Adapaun evaluasi usablity yang bisa dilakukan salah satunya dengan menggunakan SUS (System Usability Scale). SUS merupakan salah satu instrumen evaluasi yang digunakan untuk melihat usability dari sebuah produk perangkat lunak. Berdasarkan hasil evaluasi usability terhadap 30 responden mahaiswa di berbagai lintas angkatan program studi sistem informasi, platform ELMA memiliki skor rata-rata sebesar 44 dengan rating rendah dan nilai huruf F. Hal ini menunjukkan bahwa ELMA masih memiliki tingkat kegunaan/usability yang masih rendah. Sehingga perlu adanya perbaikan, diantaranya menghilangkan menu yang dirasa tidak diperlukan, memperbaiki tampilan dari forum diskusi, perbaikan plug-in fitur live conference, perbaikan terhadap tombol yang sering terjadi malfungsi, serta percepatan loading page pada paltform tersebut.
\end{abstract}

\section{ABSTRACT}

Government policy during the pandemic has an impact on changes in learning activities at the University of PGRI Madiun, where the whole process is carried out online, one of them by utilizing ELMA (E-learning of Madiun PGRI University). In practice, users complain when using the platform, one of which is a number of useless buttons, some dashboard menus that confuse users, and many other problems. However, these complaints have not been well accommodated, so it makes users feel uncomfortable using the platform, so an evaluation is needed to understand the usability condition of ELMA. It is necessary to remember one of the ELMA's mission is to support online learning through the features according to user needs. The usablity evaluation can be done either by using SUS (System Usability Scale). SUS is one of the evaluation instrument used to look at the usability of a software product. Based on the results of usability evaluation of the 30 respondents from various forces student information system study program, ELMA platform has an average score of 44 with a "Awful" and letter grade F. This shows that ELMA still has a low level 
of usability. So there needs improvement, including removing the menu that was deemed unnecessary, improve the appearance of the discussion forum, repair plug-in features of a live conference, improvements to frequent malfunctions button and speed up page loading on the platform.

Teknologi: Jurnal IImiah Sistem Informasi dengan lisensi CC BY NC SA.

\section{Pendahuluan}

Semenjak adanya era digital, studi tentang pembelajaran online merupakan topik yang populer dan hangat untuk dibicarakan (Sujito, Arifudin, \& Arini, 2019), apalagi pengguna e-learning di masa pandemi Covid-19 meningkat pesat. Hal itu dikarenakan adanya kebijakan WFH (work from home) dari pemerintah, sehingga seluruh proses kegiatan pembelajaran di kelas digantikan dengan model pembelajaran secara online atau pendidikan Jarak Jauh (PJJ) (Rusdiana, Sulhan, Arifin, \& Kamludin, 2020). Dalam kegiatan pembelajaran online, beberapa platform e-learning yang banyak digunakan adalah Moodle (Modular Object-Oriented Dynamic Learning Environment). Hal itu dikarenakan Moodle memiliki kelebihan di bagian LMS (Learning Management Systems). LMS ialah salah satu sistem yang dapat mengatur proses pembelajaran secara online dengan melibatkan mahasiswa, dosen dan administrator dalam sebuah paltform pembelajaran (Setiawati, Rahim, \& Kisbianty, 2018). Universitas PGRI Madiun (UNIPMA) di Jawa Timur merupakan salah satu perguruan tinggi swasta, yang sebagian besar proses pembelajarannya dilakukan dengan model tatap muka di dalam kelas, di mana dosen dan mahasiswa bertemu dalam sebuah ruang belajar untuk melakukan proses pembelajaran. Sebagai upaya untuk mendukung proses pembelajaran secara online serta mewujudkan ekosistem smart campus. UNIPMA mengembangkan sebuah platform edukasi yang memaksimalkan penggunaan teknologi dan sistem informasi di lingkungan kampus, yang diberi nama ELMA (Setiawan, Saifulloh, \& Kurniawan, 2019).

ELMA dikembangkan dengan memanfaatkan Moodle sebagai LMS. Moodle memiliki kelebihan, yaitu berbasis web dan bersifat open-source (Mtebe, 2015). Moodle dipilih karena sejalan dengan hasil analisis kebutuhan e-learning, di mana materi dan fasilitas ujian bisa dilaksanakan secara daring, menggunakan teknologi informasi terbaru, memiliki user interface (UI) yang baik, sistem keamanan, forum diskusi ilmiah serta memperhatikan LSM, knowledge management, dan knowledge transfer, tetapi selain memanfaatkan LMS, diperlukan juga pengemasan bentuk digitalisasi pembelajaran dalam bentuk yang lebih interaktif (Bachtiar \& Hakim, 2016). Dalam prosesnya terdapat beberapa kendala, di mana pengguna merasa mengeluh ketika mengoperasikan platform ini. Namun, keluhan dari para pengguna belum terakomodasi dengan baik. Sehingga diperlukan evaluasi untuk mengungkap kondisi usability dari faktor kepuasan, kefektifan dan efisiensi dari ELMA. Hal ini perlu dilakukan mengingat salah satu misi dari ELMA adalah mendukung pembelajaran online melalui fitur-fitur yang sesuai dengan kebutuhan pengguna. Apabila dalam pengembangannya mengabaikan kebutuhan pengguna, maka proses pembelajaran yang dikembangkan dengan LMS pun kurang bisa dirasakan manfaatnya. Hal tersebut terjadi karena pengguna akan merasa tidak nyaman, sehingga berdampak pada motivasi pembelajaran dari pengguna. Usabiliy (kegunaan) disebutkan pertama kali pada ISO 9241-11 di tahun 1998. Pada ISO tersebut dijelaskan bahwa usability menunjuk pada tingkat sebuah produk yang dapat digunakan oleh pengguna tertentu untuk mencapai tujuan spesifik dengan memperhatikan faktor efektif (effectiveness), efisien (efficiency), dan memuaskan (statisfaction) dalam sebuah konteks penggunaan (Kaya, Ozturk, \& Gumussoy, 2018), guna mengukur tingkat kepuasan, efektifitas, dan efisiensi terhadap sebuah produk (Borsci, Federici, Bacci, Gnaldi, \& Bartolucci, 2015).

System Usability Scale (SUS) merupakan salah satu instrumen evaluasi yang digunakan untuk melihat usability dari sebuah produk perangkat lunak, dan SUS terbukti menjadi alat yang sangat sederhana dan dapat diandalkan. Adapun kelebihan dari SUS antara lain menurut (Baumgartner, Frei, Kleinke, Sauer, \& Sonderegger, 2019; Sharfina \& Santoso, 2016): 1) SUS hanya terdiri dari sepuluh pertanyaan, sehingga relatif cepat dan mudah diselesaikan; 2) SUS gratis dan tidak memerlukan biaya tambahan; dan 3) SUS sangat mudah digunakan, tidak memerlukan perhitungan yang rumit, karena hasilnya berada di kisaran skor 0-100. Terakhir SUS terbukti valid dan dapat diandalkan, meskipun dengan ukuran sampel yang kecil.

Revythi dan Tselios (2019) menyebutkan bahwa SUS berhasil digunakan untuk mengukur perilaku penggunaan siswa terhadap LMS yang dimodifikasi dengan technology acceptance model (TAM), 
dengan melibatkan 345 mahasiswa tingkat universitas. SUS juga dapat digunakan untuk mengukur tingkat penerimaan siswa terhadap berbagai macam model teknologi pembelajaran. Sujito, Arifudin, dan Arini (2019) menyatakan bahwa instrumen kuesioner SUS berhasil digunakan untuk menguji usability tampilan antar muka dan pengalaman pengguna dari Lumbung Media. Lumbung Media merupakan media pembelajaran yang digunakan secara bebas untuk keperluan pembelajaran, membantu memberi rekomendasi perbaikan, pencarian dan proses produksi. Lumbung Media yang baru lebih efisien dan efektif untuk digunakan untuk mendokumentasikan media pembelajaran. Ramadhan, Soedijono, dan Pramono (2019) menyatakan SUS merupakan penelitian tindakan yang digunakan untuk mengukur tingkat kebergunaan dari web Time Excelindo, di mana web tersebut memiliki usability yang masih dapat diterima, tetapi dengan diberikan rekomendasi perbaikan.

Setiawan dan Wicaksono (2020) menyatakan bahwa SUS dapat digunakan untuk mengevaluasi usability e-learning dari Google Classroom dengan score 82,8. Hal itu menunjukkan bahwa platform tersebut sudah memenuhi unsur usability yang baik. Namun, terdapat saran untuk penambahan fitur live meeting yang dapat diakses dalam satu halaman kursus. Derisma (2020) menyatakan bahwa SUS dapat digunakan untuk menganalisis usability dari situs pembelajaran online pada topik Pemograman Komputer yang bernama CodeSaya di tingkat universitas. Hasil score sebesar 72,1 untuk pengguna yang familier, 70 untuk penguna yang belum familier, dan memiliki rating B yang artinya baik. Selain itu SUS merupakan sesuatu yang efektif dan merupakan instrumen yang reliable untuk mengukur usability dari berbagai produk dan layanan. Hasil analisis dapat disimpulkan bahwa situs pembelajaran Pemrograman Komputer telah memenuhi kriteria usability. Oleh karena itu, CodeSaya dapat diimplementasikan sebagai media pembelajaran yang layak digunakan. Sharfina dan Santoso (2016) menjelaskan bahwa SUS yang diadaptasi dengan versi bahasa Indonesia memiliki uji adaptasi dan reliabilitas sebesar 0,841. Sidik (2018) menyatakan bahwa kuesioner SUS memiliki tingkat relabilitas yang cukup baik ketika diuji cobakan terhadap web berita berbasis mobile dengan subjek penelitian 55 orang dengan usia responden minimum 18 tahun, dan maksimal 35 tahun sebesar 0,856. Hal itu dapat disimpulkan bahwa versi ini dapat digunakan oleh para peneliti yang ingin menggunakan SUS sebagai instrumen untuk melakukan pengukuran usability.

Berdasarkan penelitian dan studi sebelumnya tentang instrumen SUS, secara garis besar SUS dapat dijadikan alat pengukuran tingkat usability dari beberapa produk baik e-learning, media pembelajaran, bahkan teknologi pembelajaran dapat diadaptasi pada pengukuran usability pada LMS di UNIPMA. Tujuannya adalah dengan adanya instrumen SUS dapat diketahui apakah e-learning yang dikembangkan sudah memenuhi aspek usability yang baik. Jika belum, diharapkan terdapat rekomendasi perbaikan di masa mendatang agar ELMA menjadi produk yang lebih baik.

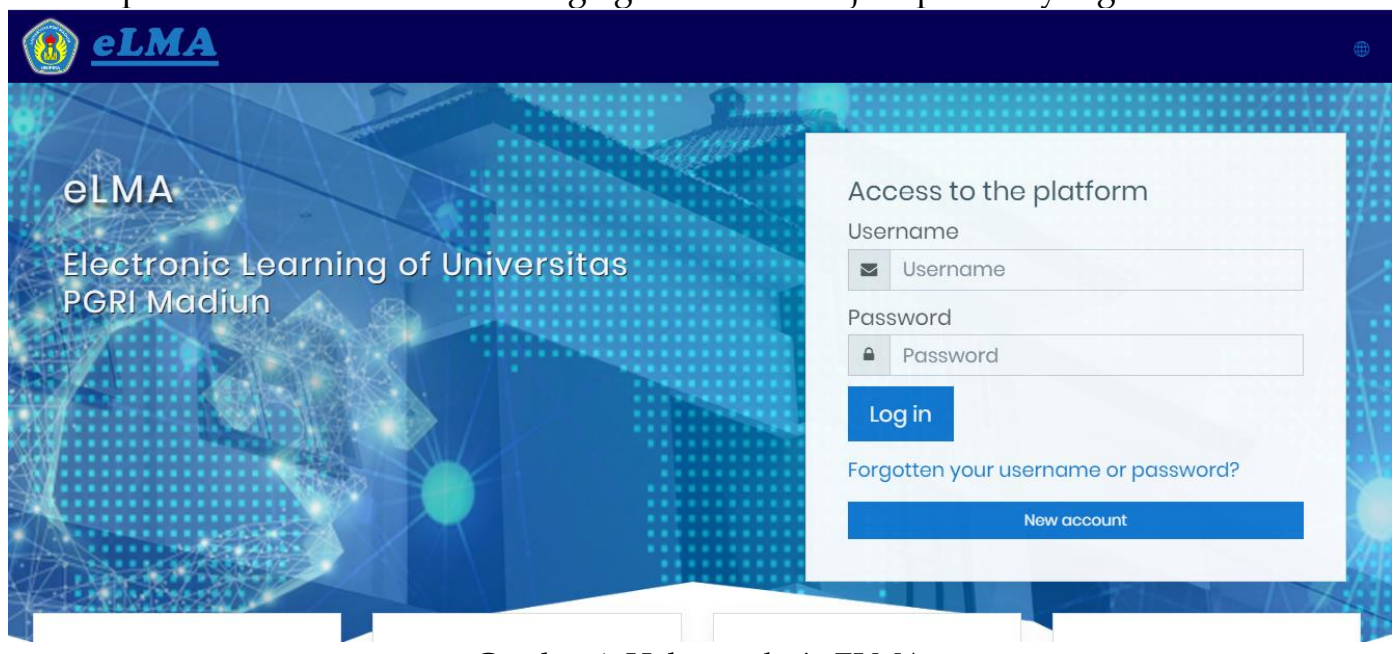

Gambar 1. Halaman login ELMA

\section{E-learning Universitas PGRI Madiun}

E-learning Universitas PGRI Madiun (ELMA) merupakan salah satu platform e-learning yang memanfaatkan Moodle. Moodle dipilih karena keunggulannya sebagai LMS (Syara, et al., 2020). Gambar 1 merupakan dashboard dari utama tampilan ELMA, di mana pengguna dapat memasukkan username dan password di kolom yang sudah disediakan, serta menu registrasi jika belum memiliki akun. 
Gambar 2 merupakan dashboard dari menu utama tampilan ELMA khusus pengguna dosen, di mana terdapat menu seperti beranda situs, kalender, berkas pribadi, serta kursus yang tersedia. Halaman dosen terdapat memiliki menu administrasi khusus, di mana dosen dapat mendapatkan hak akses sebagai admin untuk mengatur penambahan kursus, upload materi, tugas, dan melakukan penilaian terhadap tugas yang diberikan. Gambar 3 merupakan tampilan dari dashbord mahasiswa, di mana hanya terdapat menu site home, dashboard, calendar, private files, dan my courses tidak ada akses sebagai administrasi, dikarenakan mahasiswa hanya dapat mengikuti course, mengerjakan tugas, serta melakukan aktivitas sesuai dengan instruksi dari dosen.

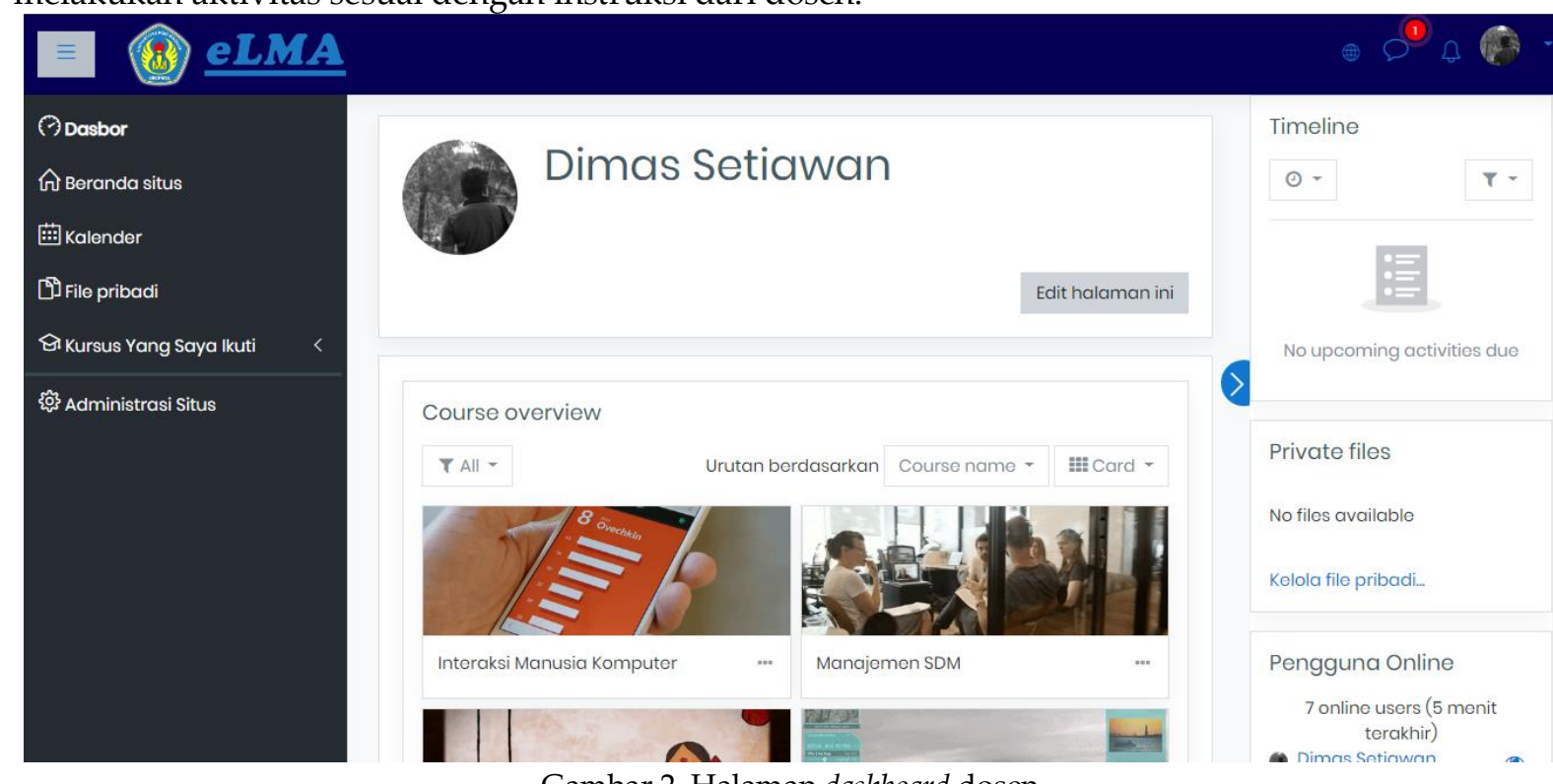

Gambar 2. Halaman dashboard dosen

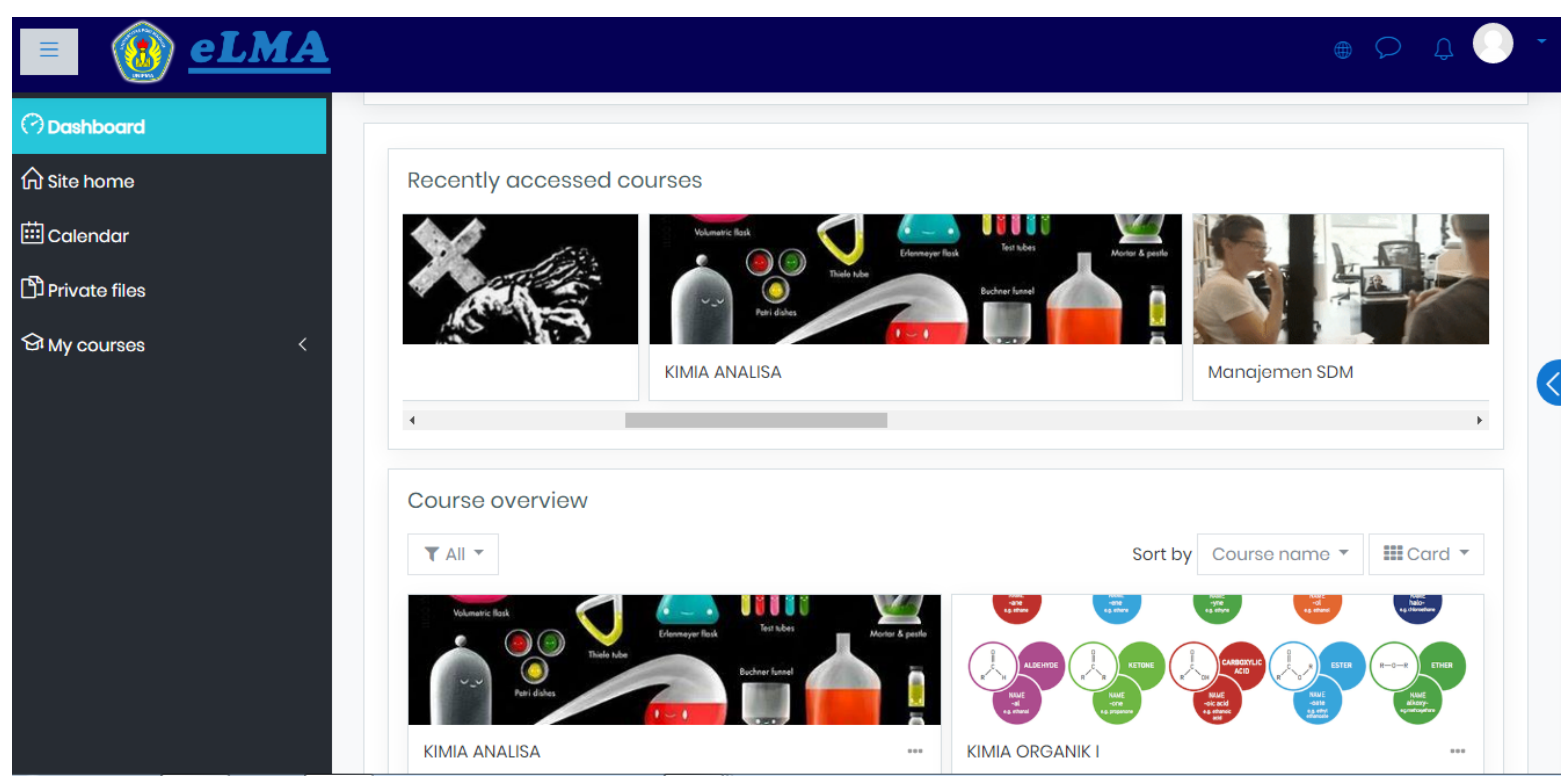

Gambar 3. Halaman dashboard mahasiswa

\section{System Usability Scale (SUS)}

System Usability Scale (SUS) adalah kuesioner yang dapat digunakan untuk mengukur usablity sistem pada komputer dari sudut pandang subjektif para pengguna. John Broke mengembangkan SUS pada tahun 1986. Sampai sekarang, SUS banyak digunakan untuk mengukur kegunaan dan memiliki beberapa kelebihan (Setiawati, Rahim, \& Kisbianty, 2018), diantaranya:

1. SUS dapat digunakan dengan mudah karena hasilnya berada di kisaran skor 0-100.

2. SUS sangat mudah digunakan, tidak memerlukan perhitungan yang rumit.

3. SUS gratis, tidak memerlukan biaya tambahan.

4. SUS terbukti valid dan dapat diandalkan, meskipun dengan ukuran sampel yang kecil.

Pengukuran usability pada learning management system perguruan tinggi ... $\quad$ http://doi.org/10.26594/teknologi.v10i1.2010 Teknologi: Jurnal IImiah Sistem Informasi dengan lisensi CC BY NC SA. 
Secara teknis, SUS memiliki 10 butir pertanyaan yang dikemas dalam bentuk kuesioner, tetapi dalam pengembangannya bisa dimungkinkan dibuat dalam bentuk gambar yang dinamakan PictorialSUS (Baumgartner, Frei, Kleinke, Sauer, \& Sonderegger, 2019), tetapi pada penelitian ini hanya digunakan kuesioner tanpa melibatkan Pictoria-SUS.

Tabel 1. SUS Questionnare (Sharfina \& Santoso, 2017)

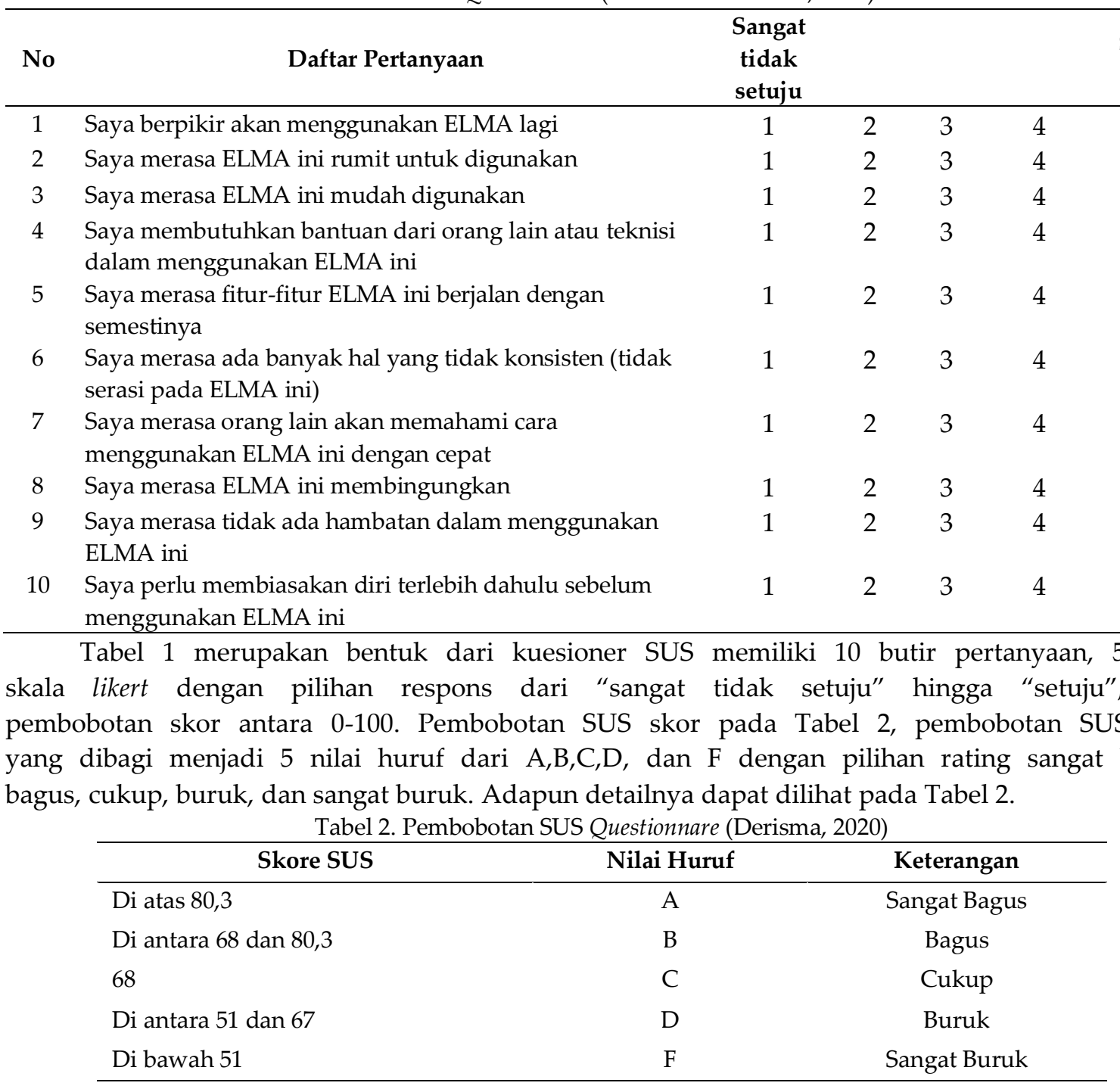

\section{Metode Penelitian}

Penelitian ini menggunakan metode penelitian kuantitatif, di mana terdapat analisis data kuantitatif dengan pengukuran tingkat usability dari e-learning yang dikembangkan dengan Moodle (ELMA) menggunakan SUS Questionnaire. Responden diambil dari sampel 30 mahasiswa dari jumlah populasi 50 orang dengan perhitungan Slovin pada Persamaan 1 (Kusuma, Noviasari, \& Marthasari, 2016), di mana $n$ adalah ukuran sampel, $N$ adalah ukuran populasi, $e$ adalah taraf kesalahan error sebesar 0,1 $(10 \%)$

$n=\frac{N}{1+N(e)^{2}}$

Responden berstatus aktif kuliah yang terdiri dari mahasiswa lintas angkatan dari program studi Sistem Informasi Universitas PGRI Madiun yang terdiri dari 30 mahasiswa yang dijadikan responden terdiri dari 15 pria dan 15 wanita. 13 mahasiswa dari angkatan semester 6, 12 mahasiswa dari angkatan semester 4, dan 5 mahasiswa dari angkatan semester 2. Responden telah mulai memakai ELMA semenjak bulan Maret 2020.

Pemilihan mahasiswa sebagai responden dikarenakan ELMA menerapkan SCL (student Center Learning), di mana pengguna yang utama adalah mahasiswa itu sendiri. Pertimbangan pemilihan 
mahasiswa di program studi Sistem Informasi, dikarenakan mereka memiliki pemahaman dasar mengenai sistem informasi, terlebih pernah mempelajari mata kuliah seperti Pemograman Dasar, Interaksi Manusia Komputer, Pengantar Teknologi Sistem Informasi dan sejenisnya. Sehingga diharapkan dapat lebih memberikan pendapat yang lebih obyektif ketika melakukan pengisian instrumen.

Penelitian ini memanfaatkan beberapa tahapan evaluasi sistem informasi berdasarkan kriteria evaluasi sistem-IT yang digunakan, di mana merupakan adaptasi dari model evaluasi sistem informasi ke-6 Cronholm dan Goldkuhl (2003) yang melibatkan unsur evaluator/peneliti dan pengguna/Mahasiswa. Adapun tahapannya sebagai berikut:

1. Evaluator melakukan studi literasi dan identifikasi permasalahan.

2. Evaluator menyiapkan instrumen untuk evaluasi sistem.

3. Evaluator mengambil beberapa sampel responden dari pengguna yang sudah memiliki pengalaman menggunakan sistem.

4. Evaluator memberikan kuesioner SUS kepada pengguna.

5. Pengguna mengisi kuesioner SUS.

6. Evaluator melakukan pengumpulan data, dan menganalisis hasil kuesioner.

7. Evaluator membuat kesimpulan, menghasilkan informasi dan rekomendasi saran.

Untuk mempermudah proses pengisian kuesioner kepada pengguna, maka SUS Questionnaire perlu diterjemahkan ke dalam Bahasa Indonesia, di mana digunakan tabel SUS yang sudah tervalidasi dengan uji reabilitas sebesar sebesar 0,841 seperti yang tertera pada Tabel 1.

Pada bagian akhir, kuesioner SUS ditambahkan kolom kritik dan saran yang wajib diisi oleh pengguna, hal ini bertujuan untuk mendapatkan data kualitatif terkait masukan, saran dan perbaikan yang perlu dilakukan oleh pengembang ELMA, untuk dijadikan acuan perbaikan supaya ELMA lebih baik. Kemudian untuk memperkuat data kuantitaif pada isntrumen SUS, maka dilakukan perhitungan terhadap poin pertanyaan manakah yang memiliki skor jumlah yang dirasa rendah sehingga diketahui variabel mana yang dirasa kurang, dengan begitu dapat dijadikan acuan untuk rekomendasi perbaikan yang bisa dilakukan oleh pengembang ELMA.

\section{Hasil dan Pembahasan}

Pada penelitian ini hanya digunakan kuesioner tanpa melibatkan Pictoria-SUS. Untuk pembuatan SUS Questionnaire, tools yang digunakan adalah SUS PDF generator, yang bisa diakses pada https://www.usabilitest.com/sus-pdf-generator, hal ini mempermudah dalam penyusuan SUS Questionnaire.

Tabel 3. Rekapitulasi hasil penyebaran SUS Questionnaire

\begin{tabular}{cccccccccccc}
\hline \multirow{2}{*}{ No } & \multirow{2}{*}{ Responden } & \multicolumn{8}{c}{ Skor Asli Penilaian Moodle (ELMA) } \\
\cline { 2 - 12 } & Q1 & Q2 & Q3 & Q4 & Q5 & Q6 & Q7 & Q8 & Q9 & Q10 \\
\hline 1 & R1 & 3 & 3 & 2 & 3 & 3 & 4 & 3 & 4 & 2 & 4 \\
2 & R2 & 4 & 3 & 3 & 3 & 3 & 4 & 3 & 4 & 2 & 4 \\
3 & R3 & 3 & 3 & 2 & 3 & 3 & 3 & 2 & 5 & 3 & 4 \\
4 & R4 & 4 & 4 & 4 & 3 & 3 & 4 & 3 & 4 & 2 & 3 \\
5 & R5 & 3 & 4 & 2 & 3 & 4 & 5 & 4 & 5 & 3 & 4 \\
6 & R6 & 3 & 3 & 3 & 4 & 3 & 4 & 2 & 4 & 4 & 5 \\
7 & R7 & 2 & 4 & 3 & 3 & 4 & 3 & 3 & 3 & 3 & 3 \\
8 & R8 & 4 & 3 & 3 & 4 & 2 & 3 & 4 & 3 & 3 & 4 \\
9 & R9 & 3 & 3 & 2 & 3 & 2 & 3 & 1 & 2 & 2 & 4 \\
10 & R10 & 2 & 5 & 4 & 3 & 3 & 3 & 2 & 5 & 3 & 3 \\
$\ldots$ & $\ldots$ & $\ldots$ & $\ldots$ & $\ldots$ & $\ldots$ & $\ldots$ & $\ldots$ & $\ldots$ & $\ldots$ & $\ldots$ & $\ldots$ \\
30 & R30 & 5 & 4 & 4 & 3 & 3 & 3 & 2 & 5 & 3 & 3 \\
\hline
\end{tabular}

Pengolahan data menggunakan Microsoft Excel, pengumpulan instrumen sebagian juga menggunakan Google Form guna mempermudah pendistribusian SUS Questionnaire. Setelah melakukan penyebaran SUS Questionnaire ke 10 responden didapat data hasil penyebaran kuesioner pada Tabel 3. 
Data yang telah berhasil dikumpulkan dihitung untuk diberikan pembobotan SUS score. Namun, terdapat aturan dalam menghitung SUS score. Berikut ini aturan-aturan saat perhitungan skor pada kuesionernya:

1. Setiap pertanyaan bernomor ganjil, score akhirnya merupakan hasil pengurangan score pengguna (x) dikurangi 1.

2. Setiap pertanyaan bernomor genap, score akhirnya didapat hasil pengurangan 5 dikurangi skor pengguna $(x)$.

3. Pembobotan SUS score didapat dari hasil penjumlahan keseluruhan score pengguna dikali 2,5. Aturan tersebut berlaku untuk satu responden, sehingga didapat keseluruhan SUS score pada Tabel 4. Tabel 4. Rekapitulasi hasil perhitungan SUS Questionnaire

\begin{tabular}{|c|c|c|c|c|c|c|c|c|c|c|c|c|c|}
\hline \multirow{2}{*}{ No } & \multirow{2}{*}{ Responden } & \multicolumn{10}{|c|}{ Skor hasil Hitung penilaian Moodle (ELMA) } & \multirow{2}{*}{$\begin{array}{c}\text { Jumlah } \\
\text { JML }\end{array}$} & \multirow{2}{*}{$\begin{array}{c}\text { Nilai } \\
\mathrm{JML} \times 2,5\end{array}$} \\
\hline & & Q1 & Q2 & Q3 & $\mathrm{Q4}$ & Q5 & Q6 & Q7 & Q8 & Q9 & Q10 & & \\
\hline 1 & R1 & 2 & 2 & 1 & 2 & 2 & 1 & 2 & 1 & 1 & 1 & 15 & 38 \\
\hline 2 & R2 & 3 & 2 & 2 & 2 & 2 & 1 & 2 & 1 & 1 & 1 & 17 & 43 \\
\hline 3 & R3 & 2 & 2 & 1 & 2 & 2 & 2 & 1 & 0 & 2 & 1 & 15 & 38 \\
\hline 4 & R4 & 3 & 1 & 3 & 2 & 2 & 1 & 2 & 1 & 1 & 2 & 18 & 45 \\
\hline 5 & R5 & 2 & 1 & 1 & 2 & 3 & 0 & 3 & 0 & 2 & 1 & 15 & 38 \\
\hline 6 & R6 & 2 & 2 & 2 & 1 & 2 & 1 & 1 & 1 & 3 & 0 & 15 & 38 \\
\hline 7 & R7 & 1 & 1 & 2 & 2 & 3 & 2 & 2 & 2 & 2 & 2 & 19 & 48 \\
\hline 8 & R8 & 3 & 2 & 2 & 1 & 1 & 2 & 3 & 2 & 2 & 1 & 19 & 48 \\
\hline 9 & R9 & 2 & 2 & 1 & 2 & 1 & 2 & 0 & 3 & 1 & 1 & 15 & 38 \\
\hline 10 & R10 & 1 & 0 & 3 & 2 & 2 & 2 & 1 & 0 & 2 & 2 & 15 & 38 \\
\hline$\ldots$ & $\ldots$ & $\ldots$ & .. & $\ldots$ & $\ldots$ & $\ldots$ & $\ldots$ & $\ldots$ & $\ldots$ & $\ldots$ & $\ldots$ & $\ldots$ & $\ldots$ \\
\hline 30 & R30 & 4 & 1 & 3 & 2 & 2 & 2 & 1 & 0 & 2 & 2 & 19 & 48 \\
\hline & Jumlah & 73 & 42 & 72 & 68 & 60 & 42 & 51 & 33 & 51 & 36 & 533 & 1333 \\
\hline
\end{tabular}

Untuk perhitungan selanjutnya, SUS score dari masing masing responden dicari score rata ratanya dengan cara menjumlahkan keseluruhan score dan dibagi dengan jumlah responden (Derisma, 2020), untuk perhitungan dapat dilihat pada Persamaan 2, di mana $\widetilde{\boldsymbol{x}}$ adalah skor rata-rata, $\sum \boldsymbol{x}$ adalah jumlah skor SUS, dan $n$ adalah skor rata-rata.

$\tilde{x}=\frac{\sum x}{n}$

Hasil perhitungan menggunakan Persamaan 2 didapat skor rata-rata untuk Moodle (ELMA) sebesar 44 dengan rating "sangat buruk" dan nilai huruf F. Dari kuesioner yang diberikan, pada kolom kritik dan saran terdapat beberapa saran perbaikan pada e-learning ELMA, diantaranya:

1. Perlu dihilangkan penempatan menu-menu yang dirasa tidak diperlukan, karena menu yang tidak diperukan ini mengganggu tampilan dari dashboard pada ELMA.

2. Terlalu banyak kursus yang ditampilkan pada halaman dasbhoard.

3. Tampilan forum diskusi yang kurang nyaman dan rumit, di mana tampilan dari kolom komentar pada forum diskusi memiliki tampilan terlalu besar dari ukuran font normal pada sebuah web, sehingga perlu dibuat lebih praktis lagi.

4. Terdapat beberapa kendala, di mana terdapat kasus tombol tidak berfungsi dengan baik ketika mengerjakan tugas/kuis, hal ini begitu menghambat proses pengerjaan tugas dan kuis yang dilakukan oleh mahasiswa.

5. Akses terhadap e-learning cukup lama dan sering terjadi Error, selain itu fitur plugin "live conference" yang belum bisa diakses oleh pengguna baik dari dosen dan mahasiswa.

6. Loading page pada ELMA masih terlalu lama untuk diakses.

Selain melakukan perhitungan terhadap jumlah SUS Score dan melakukan rekap data terhadap kolom komentar kritik dan saran, dilakukan perhitungan terhadap poin pertanyaan manakah yang memiliki skor jumlah yang paling rendah, dengan melihat selisih skor dari jumlah skor tiap pertanyaan, dengan skor ideal terhadap 30 responden. Skor ideal didapat dari nilai sempurna ketika responden memberikan nilai sempurna terhadap setiap poin pertanyaan. Dari perhitungan selisih skor ini diketahui variabel mana yang kurang, seperti yang di sajikan pada Tabel 5. 
Tabel 5. Rekapitulasi hasil perhitungan selisih skor tiap pertanyaan

\begin{tabular}{lcccccccccc}
\hline \multicolumn{1}{c}{ Nomor Pertanyaan } & $\mathbf{1}$ & $\mathbf{2}$ & $\mathbf{3}$ & $\mathbf{4}$ & $\mathbf{5}$ & $\mathbf{6}$ & $\mathbf{7}$ & $\mathbf{8}$ & $\mathbf{9}$ & $\mathbf{1 0}$ \\
\hline Jumlah skor & $\mathbf{7 3}$ & 47 & $\mathbf{7 2}$ & 68 & $\mathbf{6 0}$ & 42 & $\mathbf{5 1}$ & 33 & $\mathbf{5 1}$ & 36 \\
Skor Ideal & 120 & 0 & 120 & 0 & 120 & 0 & 120 & 0 & 120 & 0 \\
$\begin{array}{l}\text { terhadap 30 responden } \\
\text { Jumlah selisih skor }\end{array}$ & 47 & $\mathbf{- 4 7}$ & 48 & $\mathbf{- 6 8}$ & 60 & $\mathbf{- 4 2}$ & $\mathbf{6 9}$ & $\mathbf{- 3 3}$ & $\mathbf{6 9}$ & $\mathbf{- 3 6}$ \\
\hline
\end{tabular}

Tabel 5 dapat dilihat bahwa, jumlah skor selisih negatif terdapat pada poin pertanyaan nomor 2 tentang kerumitan sistem, poin pertanyaan nomor 4 tentang bantuan penggunaan sistem, poin nomor 6 tentang kekonsistenan dalam sistem, poin nomor 8 tentang kebingungan dalam penggunaan sistem, dan poin 10 tentang seberapa lama pengguna harus beradaptasi terhadap cara kerja sistem. Adapaun hal yang bisa diperbaiki pada ELMA berdasarakan pada Tabel 5 yaitu pada kerumitan sistem, bantuan penggunaan sistem, kekonsistenan sistem, akomodasi untuk mengatasi kebingungan dalam penggunaan sistem, serta solusi terhadap seberapa lama pengguna harus beradaptasi terhadap cara kerja sistem.

Dari hasil pembahasan yang telah dipaparkan, maka ELMA memiliki tingkat usability dengan rating dan grade yang masih rendah, sehingga perlu adanya rekomendasi perbaikan dengan memperhatikan beberapa masukan dan saran dari pengguna, di mana secara garis besar hal yang perlu diperbaiki diantaranya menghilangkan menu yang tidak diperlukan, memperbaiki tampilan dari forum diskusi, perbaikan plug-in fitur live conference, perbaikan terhadap tombol yang sering terjadi malfungsi, serta percepatan loading page pada paltform tersebut.

\section{Kesimpulan}

Berdasarkan hasil evaluasi usability menggunakan SUS Questionnaire terhadap 30 responden mahasiswa aktif lintas angkatan untuk platform Moodle (ELMA) mendapati skor rata-rata sebesar 40,8 dengan rating "sangat buruk" dan nilai huruf F. Berdasarakan hasil rating tersebut dapat disimpulkan bahwa ELMA memiliki tingkat usability yang masih rendah, sehingga diperlukan beberapa perbaikan agar ELMA memiliki grade/rating yang lebih baik.

Adapun hal yang bisa diperbaiki berdasarkan hasil perhitungan jumlah selisih skor tiap poin pertanyaan pada instrumen SUS yang utama ada pada kerumitan sistem, bantuan penggunaan sistem, kekonsistenan sistem, akomodasi untuk mengatasi kebingungan dalam penggunaan sistem, serta solusi terhadap seberapa lama pengguna harus beradaptasi terhadap cara kerja sistem.

Beberapa masukan dari pengguna terhadap hal yang perlu diperbaiki diantaranya menghilangkan menu yang tidak diperlukan, memperbaiki tampilan dari forum diskusi, perbaikan plug-in fitur live conference, perbaikan terhadap tombol yang sering terjadi malfungsi, serta percepatan loading page pada platform tersebut.

\section{Referensi}

Bachtiar, M. A., \& Hakim, L. (2016). Game petualangan untuk meningkatkan minat belajar siswa tentang sejarah kemerdekaan Bangsa Indonesia. Teknologi: Jurnal Ilmiah Sistem Informasi, 6(2), 80-89.

Baumgartner, J., Frei, N., Kleinke, M., Sauer, J., \& Sonderegger, A. (2019). Pictorial System Usability Scale (P-SUS): Developing an Instrument for Measuring Perceived Usability. CHI '19: Proceedings of CHI Conference on Human Factors in Computing Systems. Glasgow, Scotland UK: ACM.

Borsci, S., Federici, S., Bacci, S., Gnaldi, M., \& Bartolucci, F. (2015). Assessing User Satisfaction in the Era of User Experience: Comparison of the SUS, UMUX, and UMUX-LITE as a Function of Product Experience. Intl. Journal of Human-Computer Interaction, 31, 484-495.

Cronholm, S., \& Goldkuhl, G. (2003). Strategies for Information Systems Evaluation- Six Generic Types. Electronic Journal of Information Systems Evaluation, 6(2), 65-74.

Derisma, D. (2020). The Usability Analysis Online Learning Site for Supporting Computer programming Course Using System Usability Scale (SUS) in a University. International Journal of Interactive Mobile Technologies (iJIM), 14(9), 182-195. 
Kaya, A., Ozturk, R., \& Gumussoy, C. A. (2018). Usability Measurement of Mobile Applications with System Usability Scale (SUS). In F. Calisir, E. Cevikcan, \& H. C. Akdag (Ed.), the Global Joint Conference on Industrial Engineering and Its Application Areas, GJCIE. Nevsehir, Turkey: Springer.

Kusuma, W. A., Noviasari, V., \& Marthasari, G. I. (2016). Analisis Usability dalam User Experience pada Sistem KRSOnline UMM menggunakan USE Questionnaire. JNTETI, 5(4), 294-301.

Mtebe, J. S. (2015). Learning Management System success: Increasing Learning Management System usage in higher education in sub-Saharan Africa. International Journal of Education and Development using Information and Communication Technology (IJEDICT), 11(2), 51-64.

Ramadhan, D. W., Soedijono, B., \& Pramono, E. (2019). Pengujian Usability Website Time Excelindo Menggunakan System Usability Scale (SUS) (Studi Kasus: Website Time Excelindo). JIPI (Jurnal Ilmiah Penelitian dan Pembelajaran Informatika), 4(2), 139-147.

Revythi, A., \& Tselios, N. (2019). Extension of technology acceptance model by using system usability scale to assess behavioral intention to use e-learning. Education and Information Technologies, 24, 2341-2355.

Rusdiana, A., Sulhan, M., Arifin, I. Z., \& Kamludin, U. A. (2020). Penerapan Model POE2WE Berbasis Blended Learning Google Classroom Pada Pembelajaran Masa WFH Pandemic Covid-19. Bandung: UIN Sunan Gunung Djati.

Setiawan, D., \& Wicaksono, S. L. (2020). Evaluasi Usability Google Classroom Menggunakan System Usability Scale. Walisongo Journal of Information Technology, 2(1), 71-78.

Setiawan, D., Saifulloh, S., \& Kurniawan, I. B. (2019). Analisis Dan Perancangan Sistem Informasi LENTERA Untuk Membentuk "Smart Society“ Di Lingkungan Kampus Menggunakan Metode OOAD (Studi Kasus: Universitas PGRI Madiun). Seminar Nasional Teknologi Informasi dan Komunikasi (pp. 155-159). Madiun: Universitas PGRI Madiun.

Setiawati, A., Rahim, A., \& Kisbianty, D. (2018). Pengembangan dan Pengujian Aspek Usability pada Sistem Informasi Perpustakaan (Studi Kasus : STIKOM Dinamika Bangsa Jambi). PROCESSOR, 13(1), 1173-1188.

Sharfina, Z., \& Santoso, H. B. (2016). An Indonesian adaptation of the System Usability Scale (SUS). International Conference on Advanced Computer Science and Information Systems (ICACSIS) (pp. 145148). Malang: IEEE.

Sidik, A. (2018). Penggunaan System Usability Scale (SUS) Sebagai Evaluasi Website Berita Mobile. Technologia, 9(2), 83-88.

Sujito, F., Arifudin, R., \& Arini, F. Y. (2019). An Analysis of User Interface and User Experience Using System Usability Scale and GOMS Method. Journal of Advances in Information Systems and Technology, 1(1), 65-73.

Syara, Y., Anggoro, B., Handoko, A., Haka, N. B., Kesumawardani, A. D., \& Hidayah, N. (2020). The Use of Moodle-based Learning Management System (LMS) on MATE (Media Ajar Teori Evolusi). IOP Conf. Series: Journal of Physics: Conf. Series. IOP. 